\title{
Dwilogi Interpretasi dalam Dominasi Pembagian Harta Ber- sama: Telaah atas Putusan Mahkamah Syar'iyah Lhoksukon Nomor 168/pdt.g/2014/ms-lsk
}

\author{
Fauzah Nur Aksa, Muhammad Ikbal Maulia \\ ${ }^{1}$ Dosen Fakultas Hukum Universitas Malikussaleh \\ ${ }^{2}$ Mahasiswa Fakultas Hukum Universitas Malikussaleh
}

\begin{abstract}
Abstrak
Studi ini hendak menjawab sebuah pertanyaan mengapa terdapat problem yuridis, sosiologis dan bahkan epistemologis dalam polemik harta bersama pasca perceraian? Polemik tersebut dipecah dalam putusan Mahkamah Syar'iyah Nomor 168/Pdt.G/2014/MS-Lsk. Untuk menjawabnya, secara kualitatif, studi ini memanfaatkan pendekatan yuridis normatif yang disandarkan pada norma perundang-undangan. Dua model interpretasi ditampilkan sebagai objek formal, sekaligus juga objek material yang dioperasikan dalam rangka melahirkan putusan tersebut. Teori Ronald Dworkin dan Abi Ishaq asy-Syatibi juga dimanfaatkan untuk memperlihatkan titik-temu antara dua model interpretasi tersebut. Implikasi studi ini adalah bahwa dalam putusan Mahkamah Syar'iyah Nomor 168/Pdt.G/2014/MS-Lsk terdapat semacam dimensi epistemologis yang berpijak pada paradigm subtantif, yakni paradigma yang berpijak tidak hanya pada norma yuridis, tetapi juga kemaslahatan yang merupakan orientasi dari norma itu sendiri.
\end{abstract}

Katakunci: Dwilogi, Interpretasi, Harta Bersama, Mahkamah Syariah 


\section{PENDAHULUAN}

Studi hukum pascapercerian tentu saja tidak hanya membahas harta gono-gini, tetapi juga problem hukum lain seperti hak asuh, kewajiban nafkah dan lainnya. Petanyaannya, mengapa pembahasan harta bersama dipilih sebagai objek material studi ini? Jawabannya adalah karena suatu realitas bahwa-meskipun terdapat aturan tetap tentang bagian yang berhak diperoleh masingmasing pihak yang bercerai, namun-praktik penetapan hukumnya tidak selalu berbanding lurus dengan bunyi aturan tersebut. Persis pada titik inilah penulis memandang perlunya suatu ikhtiar untuk 'menakwil-ulang' argumentasi hukum pembagian harta bersama.

Kitab Undang-Undang $\mathrm{Hu}-$ kum Perdata Pasal 119 ayat 1 menyatakan bahwa harta bersama dihitung sejak perkawinan dilangsungkan, dan demi hukum berlakulah persatuan-bulat antara harta kekayaan suami dan istri, sekadar mengenai itu, dengan perjanjian kawin tidak diadakan ketentuan lain (Subekti dan Tjitrosudibio, 1996: 29). Tak jauh berbeda dengan KUHPerdata, Kompilasi Hukum Islam menjelaskan kedudukan harta bersama secara rinci. Pasal 85 menyatakan tentang keniscayaan dan/atau potensi ber- campurnya harta bersama dengan harta milik masing-masing (bawaan) suami-istri. Hanya saja, pada pasal selanjutnya terdapat semacam kesan penegasian terhadap potensi percampuran harta tersebut, yakni bahwa hukum asal harta bersama adalah tidak adanya percampuran antara harta suami dan harta istri dalam perkawinan. Keterangan ayat 2 pasal tersebut menjustifikasi potensi penegasian itu, bahwa harta istri tetap menjadi harta istri dan dikuasai sepenuhnya oleh istri, demikian juga harta suami tetap menjadi hak suami dan dikuasai penuh olehnya.

Apa yang tampak dari teks yuridis di atas, sekaligus juga yang menjadi objek material studi ini, adalah bukan hanya argumentasi diasporik harta bersama, melainkan juga konsekuensi logis dari sikap diasporik yang dimunculkan oleh teks itu sendiri. Di satu sisi, terdapat tuntutan atas suami-istri untuk melepaskan batas-batas hak antara harta bawaan dan harta bersama, sementara di sisi lain terdapat kesan penegasian atas tuntutan tersebut. Ia digabungkan sekaligus juga dipisahkan. Jika di kemudian hari mereka terpaksa bercerai, keduanya harus mempertimbangkan risiko konflik harta gono-gini. Konsekuensi logis yang muncul akan berimplikasi pada ketidakpastian hukum pembagian harta bersama, sebagaimana tam- 
pak pada dua dalil hukum berikut ini:

Pertama, pasal 37 berbunyi bahwa suatu perkawinan dikatakan putus sebab perceraian, dan harta bersama diatur menurut hukumnya masing-masing. Makna interpretatif dari "Diatur menurut hukumnya masing-masing" mencakup hukum agama, hukum adat dan sebagainya. Bunyi pasal ini memberikan pemahaman bahwa tidak ada aturan khusus yang mengharuskan penyelesaian sengketa harta bersama berdasarkan sistem hukum tertentu. Ia bisa diselesaikan baik berdasarkan hukum tertulis, maupun tak tertulis (adat).

Kedua, pasal 97 KHI menyatakan bahwa 1/2 (seperdua) bagi masing-masing janda atau duda cerai hidup, sementara pada sengketa harta bersama di Mahkamah Syar'iyah Lhoksukon, hakim justru menghadirkan kalkulasi berbeda. Putusan sidang dengan nomor 168/Pdt.G/2014/MS-Lsk menetapkan bahwa penggugat (suami) mendapat $1 / 3$ bagian, sementara tergugat (istri) mendapatkan 2/3 bagian dari harta bersama.

Dua pasal tersebut, ditambah dengan alasan yang melatarbelakangi putusan hakim Mahkamah Syari'ah Lhoksukon, akan menjadi objek formal sekaligus acuan analogis studi ini. Teks eksplisit keduanya yang-dalam konteks putusan hakim nomor
168/Pdt.G/2014/MS-Lsk dianggap mengalami disfungsi itu pada gilirannya difungsikan kembali tidak dalam kalkulasi statis, tetapi dinamis. Dengan demikian, konsep keadilan yang ditawarkan pun menjadi dinamis. Konsep ini mengungkap, memperlihatkan, sekaligus menyandarkan keadilan pada paham kemanfaatan (utilitarianisme) guna menghasilkan kepuasan bagi setiap individu. Henry Sidgwick (1907) dalam karyanya The Methods of Ethics, sebagaimana dikutip oleh John Rawls dengan istilah kepuasan netto:

"Masyarakat disebut tertata dengan tepat, dan karenanya adil, ketika lembaga-lembaga utamanya diatur sedemikian rupa, demi mencapai keseimbangan kepuasan netto yang merupakan hasil dari kepuasan seluruh individu anggota masyarakat yang bersangkutan (Rawls, 2011: 25)"

Konsep keadilan semacam ini berpijak pada asas kemanfaatan. Neraca keadilan yang digunakan bukan hanya menimbang keadilan berdasarkan kesamarataan, melainkan juga tanggung jawab, etika dan rasa saling menghargai.

Alhasil, dengan memanfaatkan dua model interpretasi, recht-historic interpretation dan recht-extensive interpretation, studi ini berupaya mengurai dalil-dalil hukum yang dianggap problematik, sekaligus memperlihatkan ba- 
gaimana dua model interpretasi hukum itu bekerja pada putusan Mahkamah Syariyah Lhoksukon nomor 168/Pdt.G/2014/MS-Lsk. Dengan kata lain, studi ini menempuh jalan memutar; berawal dari melacak, menganalis, menginterpretasi bahkan mengkritik objek materialnya (KHI dan Putusan Mahkamah Syar'iyah Nomor 168/Pdt.G/2014/MS-Lsk) untuk kemudian mengafirmasi objek material itu sendiri.

\section{METODE PENELITIAN}

Secara rinci terdapat tiga pokok permasalahan yang ingin ditelusuri dalam studi ini, keduanya dirumuskan dalam pertanyaan mendasar: 1) Bagaimana konsepsi hukum Islam tentang pembagian harta bersama? 2) Bagaimana analisis yuridis terhadap putusan Mahkamah Syar'iyah Nomor 168/Pdt.G/2014/MS-Lsk? 3) Bagaimana dua model interpretasi bekerja pada penetapan hukum pembagian harta bersama? Untuk menjawabnya, secara kualitatif, studi ini memanfaatkan pendekatan yuridis normatif yang memanfaatkan norma perundangundangan sebagai acuan.

Ada dua teori yang akan diterapkan dalam rangka membangun argumentasi studi ini. Keduanya dipilih karena memiliki koherensi dengan dua model interpretasi yang merupakan objek formal studi ini. Pertama, teori konten Ronald Dworkin, bersamaan dengan penerapan teori ini, rech-historie interpetation akan dimanfaatkan untuk menganalisis dan bahkan mengkritik paradigma KHI tentang pembagian harta bersama. Kritik tersebut selanjutnya akan dihubungkan dengan putusan Mahkamah Syar'iyah Lhoksukon.

Dalam bukunya yang berjudul "Law's Empire" (1986), sebagaimana dikutip oleh Mukthie Fadjar, ada empat elemen yang seharusnya diperhatikan dalam suatu sistem hukum; elemen asas, relasi, struktur dan kemenyeluruh-an (wholeness). Dari keempat elemen tersebut, elemen asas lah yang paling urgen karena ia bekerja sebagai penghubung antara satu peraturan (dalam hal ini KHI) dan peraturan lainnya (dalam hal ini putusan Mahkamah Syariah Lhoksukon)-baik yang sederajat, maupun yang berbeda secara hierakis-dengan mendasarkannya pada aspek substansi (Fadjar, 2014 :15-16).

Kedua, teori maslahah asySyatibi, bersamaan dengan penerapan teori ini, rech-extentive interpretation akan dimanfaatkan untuk mengafirmasi setelah sebelumnya mengkritik objek material studi ini. Menurut asy- 
Syatibi, kemaslahatan haruslah merujuk pada dua aspek; aspek realitas sosial (sosiologis) dan aspek khitab syar'i (epistemologis) (Syatibi, 1417 H: 44-79). Yang dimaksud dengan aspek realitas sosial adalah suatu kondisi yang menginginkan kesesuaian konsep keadilan pembagian harta bersama dengan kondisi sosial mereka (dalam hal ini hak dan kewajiaban suami-istri) ini yang dikatakan oleh as-Syatibi dengan waqa'i' alwujud (realitas yang ada). Adapun yang dimaksud dengan aspek khitab syar'i adalah bagaimana hukum itu dihasilkan dengan mencarikan argumentasi epitemologis yang sesuai dengan prinsip syar'i (Syatibi, 1417 H: 44, 77). Menurut penulis, dua teori tersebut sangat koheren dengan model penafsiran dan sumber data studi ini, karena keduanya sama-sama berfungsi menakar keadilan hukum berdasarkan substansinya.

Sumber data yang digunakan dalam studi ini meliputi: 1) data primer, seperti UndangUndang No.1 Tahun 1974 Tentang Perkawinan, Kitab Undang-Undang Hukum Perdata (KUHPer), Kompilasi Hukum Islam dan putusan Mahkamah Syar'iah Lhoksukon No. 168/Pdt.G/2014/MS-Lsk. 2) Data sekunder yang diperoleh dari karya ilmiah di bidang hukum, seperti buku referensi, skripsi, tesis, disertasi dan jurnal. 3) Sumber tersier, yakni literatur-literatur yang mendukung tema riset ini, meski tidak membahas secara khusus dan ekstentif tentangnya. Sumber hukum tersebut umumnya mencakup esai, tulisan dari internet yang sedikit-banyak menyinggung hukum pembagian harta bersama (Soekanto dan Mamuji, 2007: 13).

\section{PEMBAHASAN}

3.1. Dominasi Istri dalam Putusan Mahkamah Syar'iyah Nomor 168/Pdt.G/2014/MS-Lsk

Sebelum memperlihatkan bagaimana dominasi istri dalam putusan Mahkamah Syariah Lhoksukon, perlu terlebih dahulu mengetahui wilayah kekuasaan hakim dalam memutusakan suatu perkara. Dalam Undang-Undang RI No. 4 Tahun 2004 tentang Kekuasan Kehakiman, Pasal 28, dijelaskan tentang kewajiban hakim; menggali, mengikuti dan memahami nilainilai hukum dan rasa keadilan yang hidup dalam masyarakat. Setiap putusan hakim memiliki kekuatan yang harus ditaati oleh semua pihak, karena hakim pada dasarnya memiliki komitmen dan nurani yang sama, yakni menilai peraturan perundang-undangan yang akan dijadikan pijakan hukum dalam mengambil keputusan berdasarkan ajaran agama dan ne- 
raca keadilan (Mertokusumo: 1984: 16).

Sikap hakim tersebut secara hukum dapat dibenarkan karena ia memiliki kebebasan dalam memutuskan dan hak otonomi, sebagaimana tampak di setiap putusan selalu diawali dengan kalimat "Demi keadilan berdasarkan Ketuhanan Yang Maha Esa". Hakim juga dapat melakukan contra legem (menyimpang) terhadap pasalpasal yang dirasa tidak sesuai dengan neraca keadilan dan kebenaran. Pasal 229 Kompilasi Hukum Islam menjustifikasi contra legem tersebut; bahwa dalam menyelesaikan perkara-perkara yang diajukan kepadanya, hakim wajib memperhatikan dengan sungguhsungguh nilai-nilai hukum yang hidup di masyarakat, sehingga putusannya sesuai dengan rasa keadilan (Wantu, 2012: 5).

Dengan demikian, pertimbangan dan/atau sikap hakimdalam suatu perkara-merupakan intisari putusan yang berisi analisis, argumentasi, pendapat dan kesimpulan. Dalam suatu pertimbangan analisis, hakim wajib merujuk pada undang-undang, sementara alat bukti yang memenuhi syarat formil dan materil berfungsi memudahkan hakim dalam memutuskan suatu perkara secara adil. Untuk melihat bagaimana pertimbangan hakim dalam memutuskan perkara dominasi istri dalam pem- bagian harta bersama seperti kasus yang terdapat dalam putusan Mahkamah Syar'iyah Lhoksukon nomor 168/PDT.G/2014/MS-Lsk, perlu mencermati duduk perkara, seturut penjelasan berikut:

Seorang laki-laki berumur 48 tahun, beragama Islam, bekerja sebagai Pegawai Negeri Sipil, beralamat di Jalan Listrik Gang Oscar Nomor 12 Hagu Selatan, Kota Lhokseumawe, dalam hal ini telah memberi kuasa kepada Muhammad Nasir, SH., advokat pada kantor JN \& REKAN. Selaku penggugat, mantan suami mengajukan gugatan pembagian harta bersama Mahkamah Syar'iyah Lhoksukon terhadap mantan istrinya yang berumur 40 tahun, beragama Islam, bekerja sebagai Pegawai Negeri Sipil, bertempat tinggal di Dusun Puuk, Gampong Matang Mane, Kecamatan Tanah Luas, Kabupaten Aceh Utara. Penggugat dan tergugat yang sudah bercerai di Mahkamah Syar'iyah Lhoksukon berdasarkan akta cerai Nomor 31/AC/2014/MS-Lsk, pada tanggal 28 Januari 2014. Selama perkawinan penggugat dan terguggat tidak mempunyai keturunan, melainkan harta bersama (seuharkat).

Berdasarkan putusan hakim Mahkamah Syar'iyah Lhoksukon tersebut suami mendapat $1 / 3$ (sepertiga) bagian harta bersama, sementara istri memperoleh $2 / 3$ (dupertiga), dengan demikian istri 
mendapat bagian lebih besar dari suami dalam pembagian harta bersama. Jika merujuk pada peraturan yang ada,-mengenai pembagian harta bersama-baik UndangUndang Nomor 1 tahun 1974 tentang Perkawinan, Kitab UndangUndang Hukum Perdata maupun Kompilasi Hukum Islam, tidak ditemukan aturan yang menyebutkan bahwa istri berhak memperoleh bagian lebih besar dari suami, tetapi peraturan yang terkandung dalam tiga buku hukum tersebut cenderung membagi harta bersama dengan kalkulasi 50:50. Artinya, perlu menelusuri alasan pertimbangan hakim dalam mengambil sikap contra legem, sekaligus mengabaikan peraturan tekstual yang biasanya menjadi rujukan.

3.2. Putusan Mahkamah Syar'iyah Nomor 168/Pdt.G/2014/MSLsk dalam Rech-extentive Interpretation

Ekspresi Budaya Tradisional berakar dalam tiga kata, tradisi, budaya dan ekspresi.Untuk "ekspresi", itu berarti untuk mengungkapkan atau tujuan yang jelas, ide atau perasaan.Budaya dalam bahasa Inggris sesuai dengan "budaya" di Indonesia (Koentjoroningrat, 2009: 69). Hal ini berakar pada bahasa Sansekerta "budhayah" yang berarti pikiran atau intelektual (Mulyana, 2006: 59). Secara umum, budaya dapat didefinisikan sebagai sesuatu yang dihasilkan oleh pikiran manusia dan intelek untuk mengembangkan dan mempertahankan hidup mereka di lingkungan mereka. Ekspresi Budaya Tradisional adalah bagian dari kehidupan budaya masyarakat sebagai pemilik. ekspresi budaya tradisional sudah mengandung beberapa nilai seperti ekonomi, spiritualitas dan komunalitas.

Rech-extentive Interpretation yang dalam bahasa Indonesia disebut penafsiran ekstensif adalah penafsiran dengan memperluas arti kata-kata dalam peraturan perundang-undangan sehingga suatu peristiwa dapat dimasukkan ke dalamnya. Sebuah perkataan dimaknai secara lebih luas dari pada sekadar arti kata menurut kamus atau makna yang dilazimkan dalam percakapan sehari-hari, aliran listrik yang ditafsirkan sebagai benda (Daliyo, 2001: 115). Demikian pula status suami tidak bekerja yang disandang oleh penggugat dapat ditafsirkan sebagai pengabaian terhadap kewajiban nafkah, sehingga meniscayakan putusan yang berbeda dengan ketentuan pembagian 50:50.

Sejauh penelusuran penulis, setidaknya terdapat lima pertimbangan hukum yang mendasari putusan tersebut: 
Pertama, bahwa yang menjadi norma dasar pembagian harta bersama adalah pasal 97 Kompilasi Hukum Islam, (janda/duda cerai hidup masing-masing berhak seperdua harta bersama). Menurut majelis hakim, norma tersebut sepadan dengan ketentuan pasal 80 ayat 2 Kompilasi Hukum Islam, yakni suami wajib melindungi istri dan memberikan keperluan hidup berumah tangga. Norma ini adalah suatu kelaziman bukan hanya dalam tinjauan sosial, melainkan juga agama yang mewajibkan suami berusaha sementara istri yang mengatur hasilnya.

Jika dihubungkan dengan kasus perkara a quo, berdasarkan bukti-bukti yang ada, diketahui bahwa: 1) Tergugat diangkat sebagai Pegawai Tidak Tetap (Bidan Desa/PTT) di Desa Leupon Siren, Kecamatan Tanah Luas sejak tanggal 01 Oktober 1994. 2) Tergugat menikah dengan Penggugat pada tanggal 16 Mei 1995. 3) Tergugat diangkat sebagai Calon Pegawai Negeri Sipil (CPNS) sejak tanggal 01 Desember 2000, dan kemudian diangkat sebagai Pegawai Negeri Sipil (PNS) sejak 01 Februari 2002. Dalam jawabannya, Tergugat menyatakan ketika menikah dengan Tergugat, Penggugat tidak mempunyai pekerjaan tetap. Tergugat yang bekerja sebagai bidan PTT lah membiayai seluruh kebutuhan rumah tangga. Penggugat hanya mendampingi Tergugat ketika bertugas, dan pada Tahun 2000 barulah Penggugat mulai bekerja sebagai tenaga bakti di Kantor Bappeda Lhokseumawe. Pada saat itu transportasi ke kantor senilai Rp. 50.000.- perhari ditanggung oleh Tergugat. Tahun 2007 Penggugat diangkat sebagai PNS dan pada kahirnya mereka bercerai pada Tahun 2013. Selama pernikahan berlangsung, hampir semua keperluan rumah tangga dibiayai/dipenuhi oleh Tergugat. Demikian pula, hampir semua objek sengketa dibangun dan dibeli dari uang penghasilan Tergugat; baik penghasilan sebagai PNS, maupun sebagai bidan praktik swasta (BPS) di rumah, sementara penghasilan Penggugat tidak jelas penggunaannya. Jawaban tersebut dikuatkan berdasarkan keterangan saksi-saksi Penggugat.

Kedua, berdasarkan pertimbangan pertama, dengan kata lain Tergugat telah dengan sengaja melalaikan kewajibannya sebagai suami sebagaimana diamanatkan QS. An-Nisa: 34, Pasal 31 ayat (3) dan Pasal 34 ayat (1) dan (2) Undang-Undang Nomor 1 Tahun 1974), serta Pasal 80 ayat (4) dan Pasal 83 ayat (1) dan (2) Kompilasi Hukum Islam, atau justru Tergugat menjadi kepala keluarga merangkap ibu rumah tangga, maka jika dikalkulasikan, tidak ditemukan keseimbangan peran antara peng- 
gugat dan tergugat. Karenanya, membagi rata harta bersama kepada Penggugat dan Tergugat dipandang tidak memenuhi rasa keadilan.

Ketiga, berdasarkan faktafakta hukum dan/atau kasus-kasus yang menyangkut pembagian harta bersama yang hampir serupa dengan perkara ini-di antaranya adalah Putusan Mahkamah Agung Nomor 266 K/AG/2010, tanggal 12 Juli 2010-hakim menyatakan bahwa istri mendapat $3 / 4$ (tiga perempat) bagian dari harta bersama, karena harta bersama tersebut dihasilkan oleh istri dan suami tidak memberikan nafkah terhadap anak dan istri selama 11 tahun."

Keempat, sebagai pembanding dalam pertimbangan, hakim merujuk pendapat ahli hukum Islam, Drs. H.M. Anshary MK, SH.,M.H. dalam bukunya, "Hukum Perkawinan di Indonesia: Masalahmasalah Krusial", Yogyakarta: Pustaka Pelajar, 2010, Cet. Ke-1, hlm. 169 , yang menyatakan:

"Jika terjadi bahwa suami bekerja mencari nafkah dan istri pun bekerja mencari nafkah, maka hukum mencari nafkah bagi suami adalah wajib sedangkan bagi istri adalah sunnah. Dan apabila suami lalai melakukan tanggung jawab terhadap pemenuhan keperluan rumah tangga sedangkan istri yang berusaha mencari nafkah, maka jika terjadi perceraian, suami tidak berhak sama sekali dari harta yang dicari istri tersebut."

Kelima, majelis hakim berani menyampingkan ketentuanketentuan yang terdapat dalam peraturan-peraturan yang ada demi rasa keadilan. Dengan pertimbangan atas alat-alat bukti, saksisaksi dan hukum yang hidup dalam masyarakat serta perilaku penggugat sebagai suami terhadap istrinya, maka penggugat layak diberi hak $1 / 3$ dari harta bersama, sementara sisanya $2 / 3$ (dua pertiga) bagian adalah hak tergugat. Meskipun tidak sesuai dengan ketentuan-ketentuan dalam peraturan yang ada, namun keberanian hakim dalam memutuskan persentase pembagian harta bersama ini merupakan sikap atau tindakan yang sesuai dengan tujuan dari hukum itu sendiri yaitu keadilan.

Jika melihat kepada putusan nomor 168/Pdt.G/2014/MSLsk, setalah dibacakan tentang pembagian harta bersama, dipahami bahwa putusan yang berkekuatan hukum tetap ini pada intinya menyatakan bahwa objekobjek yang telah dipertimbangkan dan terbukti sebagai harta bersama antara penggugat dan terguggat-dan karena objek-objek tersebut berada dalam penguasaan terguggat maupun penggugatmaka majelis hakim menghukum penggugat dan tergugat atau siapapun yang menguasai objek tersebut secara melawan hak/hukum 
untuk membagi dan menyerahkan hak bagian penggugat dan tergugat dari objek-objek tersebut sesuai dan sebesar hak bagiannya dalam keadaan utuh dan terlepas dari segala ikatan hukum dengan pihak ketiga. Jika tidak dapat dibagi dalam bentuk barang (natura), bagian akan dilelang dimuka umum oleh pejabat yang berwenang pada Kantor Lelang Negara, dan hasilnya $1 / 3$ (sepertiga) bagian untuk penggugat dan sisanya $2 / 3$ (dua pertiga) bagian untuk tergugat. Jika objek-objek harta bersama yang ada pada tergugat sudah dijual seperti mobil ataupun tanah maka tergugat harus mengganti ataupun membayar $1 / 3$ (sepertiga) bagian objek tersebut dan diserahkan kepada penggugat.

Melihat putusan yang diputuskan oleh majelis hakim tidak sesuai dengan ketentuanketentuan peraturan yang ada, yakni membagi harta bersama menjadi dua setengah untuk suami dan setengah untuk istri. Putusan ini tidak bertentangan dengan peraturan apapun karena majelis hakim memutuskan untuk menyampingkan ketentuan-ketentuan pada peraturan yang ada demi mencapai tujuan keadilan, terlebih bahwa hakim juga memliki hak istimewa dan/atau kapasitas dalam memutuskan suatu perkara. Dengan demikian, akibat hukum yang timbul setelah putusan ini adalah mutlak dan berkekuatan hukum tetap, karenanya kedua belah pihak harus melaksanakannya dengan baik dan benar sesuai yang telah diputuskan.

\subsection{Kompilasi Hukum Islam da- lam Rech-historisce Interpre- tation}

Pada sub-bab kali ini penulis akan memperlihatkan bagaimana interpretasi historis bekerja dalam menafsirkan kalkulasi KHI atas pembagian harta bersama. Menurut Ph. Vissert Hoft dalam Rechtsvinding yang diterjemahkan B. Arief Sidharta (2001), Setidaknya ada dua model interpretasi historis; penafsiran menurut sejarah undang-undang dan penafsiran menurut sejarah hukum. Model pertama memfokuskan diri pada latar belakang sejarah perumusan naskah; bagaimana perdebatan yang terjadi ketika naskah itu hendak dirumuskan. Karenanya, ia membutuhkan kajian mendalam tentang notulen-notulen rapat, catatancatatan pribadi peserta rapat, tulisan-tulisan peserta rapat yang tersedia baik dalam bentuk tulisan ilmiah maupun komentar tertulis yang pernah dibuat, otobiografi yang bersangkutan, hasil wawancara yang dibuat oleh wartawan dengan yang bersangkutan, atau wawancara khusus yang sengaja 
dilakukan untuk keperluan menelaah peristiwa yang bersangkutan. Model kedua mencari makna yang dikaitkan dengan konteks kemasyarakatan masa lampau. Pencarian makna tersebut juga merujuk pendapat-pendapat pakar dari masa lampau, termasuk pula merujuk kepada norma-norma hukum masa lalu yang masih relevan. Demikian pula pada $\mathrm{KHI}$, studi ini akan menafsirkan maksud yang terkandung dalam kalkulasi KHI dengan pertimbangan sejarah sosial masyarakat Indonesia dan sejarah hukum Islam.

Sejak masa kenabian hingga prakodifikasi hukum Islam belum ditemukan literatur yang membahas aturan harta bersama. Teks Q.S. An-Nisa: 34 tentang leadership (qawwam) dalam rumah tangga dan Q.S. At-Talaq: 6 tentang kewajiban nafkah dan tempat tinggal, hanya mengisyaratkan peran dan kewajiban memenuhi kebutuhan rumah tangga, tidak menyebutkan harta bersama (Ramulyo, 1995: 32). Dalam Islam harta kekayaan istri tetap menjadi milik istri dan dikuasai penuh olehnya, demikian pula harta kekayaan suami. Masing-masing pasangan memiliki harta benda secara perseorangan yang tidak bisa diganggu. Suami yang menerima pemberian, warisan dan sebagainya, berhak menguasai sepenuhnya harta yang diterima, tanpa ikut campur pihak istri. Demikian halnya bagi istri yang menerima pemberian, warisan, hibah dan sebagainya, berhak menguasai sepenuhnya harta yang diterimanya itu tanpa ikut campur suami.

Hal ini terjadi karena pada umumnya pengarang kitab-kitab fiqh adalah orang Arab yang tidak mengenal adanya pencaharian bersama suami-istri. Jika pun ada, tak lain hanyalah perkongsian atau apa yang dalam terminologi Arab disebut syirkah (Ismuha, 1978: 38). Artinya, upaya kodifikasi hukum Islam tentang harta bersama hanyalah semacam ikhtiar para ulama Indonesia dalam mencarikan dalil bagi hukum harta bersama. Syirkah yang biasanya berada pada wilayah muamalah dimigrasikan ke wilayah munakahah. Dengan menggunakan metode qiyas, para intelektual Muslim pada masa itu melihat titik-temu antara syirkah dan kemudian diterapkan pada hukum pembagian harta bersama (Djazuji dan Aen, 2000: 121). Ia dapat di-qiyas-kan dengan syirkah atas pemahaman bahwa istri adalah pasangan sekaligus tim yang bekerjasama dalam membangun rumah tangga, meskipun tidak ikut bekerja dalam pengertian yang sesungguhnya (Susanto, 2008: 59).

Harta bersama kemudian kategorikan ke dalam syirkah 
mufawadhah dan/atau syirkah abdan. Syirkah mufawadhah adalah suatu bentuk perkongsian dua belah pihak yang melakukan kegiatan usaha, dan pihak ketiga sebagai pemodal, sementara syirkah abdan adalah perkongsian dua pihak atau lebih yang masingmasing anggotanya hanya melakukan kegiatan usaha, namun tidak memberikan modal. Adapun peng-qiyas-an antara harta bersama (gono-gini) dengan syirkah dapat pula dipahami melalui penjelasan bahwa percampuran harta kekayaan suami dan istri merupakan harta kekayaan tambahan karena adanya usaha bersama antara mereka berdua. Kosekuensi logisnya, jika terjadi perceraian di antara mereka, harta tersebut harus dibagi dengan berdasarkan saham masing-masing suami atau istri, atau dibagi secara merata (As'ad, 2010: 5-6).

\section{Para perumus Kompilasi} Hukum Islam menegosiasikan syirkah abdan dengan hukum adat. Metode pendekatan ini tidak bertentangan dengan kebolehan menjadikan 'urf (adat kebiasaan/tradisi) sebagai sumber hukum. Sekaligus senafas dengan kaidah yang "al adah muhakkamah". Menurut mereka, gono-gini adalah konsekuensi dari adanya hubungan perkawinan yang senafas dengan substansi Q.S.
An-Nisa: 21 yang menyebut perkawinan sebagai suatu perjanjian suci, kuat dan kokoh (mitsaqan ghalizha). Dengan demikian, perkawinan yang dilakukan melalui ijab qabul dan telah memenuhi syarat dan rukunnya merupakan syirkah antara suami dan istri.

Dalam memigrasikan syirkah abdan dari wilayah muamalah ke wilayah munakah, argumentasi yang digunakan adalah pernyatan al-Quran bahwa pernikahan adalah ikatan yang kuat (mitsaqan ghali$z a$ ). Ketika literatur-literatur fikih pada umumnya membahas ikatan perkongsian pada bab muamalah, Kompilasi Hukum Islam justru memindahkannya ke dalam pembahasan munakahah. Artinya, terdapat perbedaan antara kajiankajian hukum Islam klasik dengan kajian hukum Islam saat ini.

Konklusi logisnya menyatakan meskipun tidak ditemukan teks al-Quran, hadis, atau literatur fikih yang meyebutkan aturan harta bersama, upaya perumusan aturan tentangnya adalah suatu keniscayaan. Status perumusan hukum harta bersama yang bersifat ijtihadi (interpretatif) tentu saja bukanlah ketetapan final, karena ia merupakan negosiasi dua aspek hukum: 1) penjelasan subtantif suatu perkawinan dan 2) pertimbangan sosiologi suatu masyarakat ('urf), yakni peran istri sebagai pe- 
nyeimbang suami yang berkewajiban mencari nafkah.

Selanjutnya, nalar yuridis di atas akan dibahas lebih mendalam pada pembahasan Titik-temu Rech-historisce Interpretation dan Rech-extentive Interpretation dalam Pembagian Harta Bersama berikut ini.

\subsection{Titik-temu Rech-historisce Interpretation dan Rech- extentive Interpretation da- lam Pembagian Harta Bersa- ma}

Tidak semua metode penafsiran dapat disebut sebagai penafsiran hukum. Suatu metode penafsiran dapat diakui sebagai penafsiran hukum jika dilakukan dalam 'kegiatan juridis' (Mertokusumo \& Pitlo, 1993: 36). Kegiatan yuridis yang dimaksud di sini adalah penalaran dalam rangka menemukan hukum yang berlaku atas suatu kasus yang sedang terjadi. Dalam kaitannya dengan hal ini, penalaran yuridis bagi seorang hakim berfungsi untuk menentukan suatu putusan dan/atau hukuman. Ia mempunyai ciri khusus yang membedakannya dengan kegiatan berpikir pada umumnya, yakni bersifat logis dan analitis (Nurjaya, 1983: 302).

Ada perbedaan mendasar antara sekadar penalaran logis dan penalaran analitis. Penalaran logis menuntut adanya kegiatan berpikir berdasarkan pola dan logika tertentu, sementara penalaran analitis menuntut kegiatan berpikir yang menyandarkan diri pada analisis yang berpijak pada logika itu sendiri. Dalam kaitannya dengan aspek yuridis, penalaran analitis harus berisikan logika hukum. Pola ini berbeda dengan penalaran masyarakat umum yang cenderung non-analitis, karena mengutamakan perasaan dan intuisi. Perbedaan itu semakin kentara dalam kasus kanibalisme Sumanto mengemuka. Bagi masyarakat, apa yang dilakukan Sumanto merupakan perbuatan keji dan menjijikan. Perasaan dan intuisi masyarakat terluka oleh peristiwa ini, sehingga mereka menginginkan Sumanto dijatuhi hukuman seberatberatnya.

Sementara itu, dalam kegiatan yuridis, ketika ditemukan kasus yang harus diadili, seorang hakim tidak serta-merta menjatuhkan putusan, melainkan harus terlebih dahulu melakukan pengujian dan analisis pada aturan hukum yang berlaku; berawal dari melakukan pengujian terhadap buktibukti yang ada untuk memperjelas suatu peristiwa hukum telah terjadi, hingga melakukan melakukan penafsiran pada suatu undangundang terkait dengan hal tersebut. Jika pasal yang akan diterapkan dalam suatu kasus adalah 
pasal 406 KUHP tentang tindakan perusakan barang, hakim terlebih dahulu melakukan penafsiran apakah mayat terkategorisasi sebagai barang atau atau hal lain? Persis pada titik inilah logika analisis yuridis terapkan terhadap istilah barang. Penafsiran yuridis yang demikian itu disebut dengan rechextentive interpretation.

Seirama dengan itu, putusan Mahkamah Syar'iyah Lhoksukon Nomor 168/Pdt.G/2014/MsLsk berpotensi ditafsirkan dengan rech-extentive interpretation. Pasal $97 \mathrm{KHI}$ tentang norma dasar pembagian harta bersama dipadankan dengan dengan ketentuan pasal 80 ayat 2 Kompilasi Hukum Islam, yakni suami wajib melindungi istri dan memberikan keperluan hidup berumah tangga. Upaya memadankan pasal 97 dengan pasal 80 ini merepresentasikan penerapan rech-extentive interpretation. Atas dasar ini, majelis hakim kemudian memunculkan lima pertimbangan hukum yang mendasari putusan tersebut, sebagaimana disebutkan pada pembahasan Putusan Mahkamah Syar'iyah Nomor 168/Pdt.G/2014/MS-Lsk dalam Rech-extentive Interpretation di atas.

Lebih lanjut, majelis hakim berpendapat bahwa norma ini adalah suatu kelaziman bukan hanya dalam tinjauan sosial, melainkan juga agama yang mewajibkan s- uami berusaha, sementara istri yang mengatur hasilnya. Artinya, yang dikatakan majelis hakim adalah bukan hanya tentang pemberlakuan rech-extentive interpretation, melainkan juga penerapan teori maslahah asy-Syatibi, yakni bahwa putusan hukum harus berorientasi pada kemaslahatan yang merujuk pada dua aspek; aspek sosiologis (realitas sosial) dan aspek epistemologis (khitab syar'i).

Yang dimaksud dengan aspek sosiologis di sini adalah pandangan etis masyarakat Lhoksukon terhadap sikap suami yang bergantung hidup pada usaha istri, sementara yang dimaksud dengan aspek epistemologis adalah bahwa perintah memberikan bagian harta lebih dari setengah kepada istri lahir dari kewajiban suami sebagai pengayom (qawwam) bagi istrinya. Dengan demikian, putusan hakim menghadirkan pertimbangan sosiologis berdasarkan pola dan logika tertentu, sekaligus menyandarkan diri pada analisis yuridis yang berpijak pada logika itu sendiri.

Tak hanya potensi penerapan rech-extentive interpretation, putusan majelis hakim juga membuka ruang penerapan rechhistorisce interpretation. Penerapan historis yang pada awalnya dimanfaatkan untuk mengkritisi argumentasi hukum pembagian 
harta bersama, pada gilirannya digunakan untuk mengafirmasi hukum itu sendiri. Hal itu menjadi niscaya karena-meskipun dalam sejarah sosial hukum Islam tidak didapati fakta pensyariatan hukum pembagian harta bersama, namunterdapat ruang regulasi yang disandarkan pada maksud pensyariatan (maqasid syariah), yakni pada tujuan memelihara harta (hifz mal).

Terlepas dari pembahasan ini, jika dikaitkan dengan putusan hakim, model kedua dari rechhistorisce interpretation seirama dengan argumentasi mejelis hakim dalam hal mencari makna yang dikaitkan dengan konteks kemasyarakatan masa lampau. Ketika kultur etis masyarakat Lhoksukon meyakini bahwa suami tidak dibenarkan bergantung hidup istri, maka maknanya adalah suami telah melakukan pelanggaran etika kultural yang dipercayai secara turun-temurun, tak terkecuali pendapat-pendapat pakar dari masa lampau; dalam hal ini pendapat ahli hukum Islam, Drs. H.M. Anshary MK, SH., M.H. dalam bukunya, "Hukum Perkawinan di Indonesia: Masalah-masalah Krusial", Yogyakarta: Pustaka Pelajar, 2010, Cet. Ke-1, hlm. 169, yang menyatakan:

"Jika terjadi bahwa suami bekerja mencari nafkah dan istri pun bekerja mencari nafkah, maka hu- kum mencari nafkah bagi suami adalah wajib sedangkan bagi istri adalah sunnah. Dan apabila suami lalai melakukan tanggung jawab terhadap pemenuhan keperluan rumah tangga sedangkan istri yang berusaha mencari nafkah, maka jika terjadi perceraian, suami tidak berhak sama sekali dari harta yang dicari istri tersebut."

Rech-historiche interpretation ini kemudian dijustifikasi dengan teori Dworkin yang menyatakan ada empat elemen yang seharusnya diperhatikan dalam suatu sistem hukum; elemen asas, relasi, struktur dan kemenyeluruh-an (wholeness). Dari keempat elemen tersebut, elemen asas lah yang paling urgen karena ia bekerja sebagai penghubung antara satu peraturan (dalam hal ini KHI) dan peraturan lainnya (dalam hal ini putusan Mahkamah Syariah Lhoksukon)-baik yang sederajat, maupun yang berbeda secara hierakis-dengan mendasarkannya pada aspek substansi.

Kalimat terakhir pada pernyataan Dworkin merupakan kata-kunci bagi penulis untuk mengupayakan titik-temu antara dua model penafsiran di atas pada kasus pembagian harta bersama di Mahkamah Syar'iyah Nomor 168/Pdt.G/2014/MS-Lsk. Ketika rech-extentive interpretation 
memaknai secara lebih luas sebuah perkataan dari pada sekadar arti kata menurut kamus atau makna yang dilazimkan dalam percakapan sehari-hari, rech-historice interpretation juga memiliki fungsi yang sama yakni mendasarkan suatu peraturan pada aspek substansi. Suami tidak bekerja atau bergantung hidup kepada istri dimaknai penelantaran sekaligus pengabaian pada substansi kewajiban mencari nafkah, yakni tanggung jawab yang merupakan elemen asas bagi terciptannya suatu keadilan, keseimbangan dan keharmonisan dalam sebuah keluarga. Inilah yang disebut Dworkin dengan terma kemenyeluruhan (wholeness).

\section{KESIMPULAN}

Ada dua pion penting yang dapat disimpulkan dari pembahasan studi ini. Pertama, hukum Islam pada dasarnya tidak mengenal tentang konsep harta bersama, namun penetapan hukum pembagian harta bersamajika didasari kaidah dar al mafasid muqaddaf ala jalb al-masalihbukan merupakan suatu kebertentangan dengan dengan hukum Islam. Ia menempuh jalan ketiga, yakni apa yang disebut syirkah. Karenanya, kalkulasi harta bersama pun tidak bersifat statis, sebagaimana kalkulasi waris dalam al-
Quran. Hanya saja, putusan yang majelis yang yang tidak merujuk pada kalkulasi statis berpotensi untuk ditafsirkan-ulang bahkan dengan beberapa teori, pendekatan dan model penafsiran.

Kedua, jika ditafsirkan menggunakan rech-extentive interpretation dan rech-historisce interpretation, tampak bahwa pertimbangan majelis hakim Mahkamah Syar'iyah Lhoksukon yang Putusan Nomor 168/Pdt.G/2014/MS-Lsk adalah pertimbangan subtantif. Pertimbangan ini relatif tepat karena tidak hanya mendapatkan justifikasi teoretis dari pakar filsafat hukum Islam Abu Ishaq asySyatibi, tetapi juga pakar filsafat hukum Barat, Ronald Dworkin. Pada wilayah substansi inilah dwilogi interpretasi itu bekerja.

\section{DAFTAR PUSTAKA}

Abdurrahman. 2004. Kompilasi Hukum Islam Di Indonesia. Jakarta: Akademika Presindo.

As'ad, A. R. 2010. Gono-Gini dalam Perspekti Hukum Islam. Jurnal Pengadilan Agama.

Asy-Syatibi. 1417 H. Al-Muwafaqat. Saudi Arabia: Dar Ibn 'Affan li anNasyr wa at-Tauzi'.

Djazuli, A. dan Aen, N, I. Ushul Fiqh Metodologi Hukum Islam. Jakarta: Raja Grafindo Persada, 2000. 
Hartono, S. 1994. Penelitian Hukum di Indonesia Pada Akhir Abad ke20. Bandung: Alumni.

Herawati, A. 2011. Kompilasi Hukum Islam (KHI) sebagai Hasil Ijtihad Ulama Indonesia. Hunafa: Jurnal Studia Islamika. Vol. 8 No. 2 .

Ibrahim, J. 2006. Teori \& Metodologi Penelitian Hukum Normatif. Malang: Bayumedia Publishing.

Ismuha. 1978. Pencaharian Bersama Suami Istri di Indonesia. Jakarta: Bulan Bintang.

Manan, A. 2006. Aneka Masalah Hukum Perdata Islam di Indonesia. Jakarta: Kencana.

Mertokusumo, S. 1984. Bunga Rampai Ilmu Hukum. Yogyakarta: Liberty.

Rafiq, A. 1995. Hukum Islam di Indonesia. Jakarta: Raja Grafindo Persada.

Ramulyo, M., I. 1995. Hukum Perkawinan, Hukum Kewarisan, Hukum acara Peradilan Agama dan Zakat Menurut Hukum Islam. Jakarta: Sinar Grafika.

Soekanto, S. 1998. Penelitian Hukum Normatif. Jakarta: Raja Grafindo Persada.
Soekanto, S., \& Mamudji, S. 2007.

Penelitian Hukum Normati Suatu Tingjauan Singkat. Jakarta: PT. Raja Grafindo Persada.

Subekti, R., \& Tjitrosudibio, R. 2002. Kitab Undang-Undang Hukum Perdata. Jakarta: PT. Pradmya Paramita.

Susanto, H. 2006. Pembagian Harta Gono-Gini saat Terjadinya Perceraian, Pentingnya Perjanjian Perkawinan untuk Mengantisipasi Masalah HartaGono-Gini. Jakarta: Visimedia.

Undang Nomor 1 Tahun 1974, Peraturan Pemerintah Nomor 9 Tahun 1974. Cet. I. Medan: Zahir Trading Co.

Utrecht, 1983. Pengantar Dalam Hukum Indonesia, terj. Moh. Saleh Djindang. Jakarta: PT. Ichtiar Baru.

Wantu, M, F,. 2012. Mewujudkan Kepastian Hukum, Keadilan, Dan Kemanfaatan Dalam Putusan Hakim di Peradilan Perdata. Jurnal Dinamika Hukum, Gorontalo, Vol 3 No. 3.

Widiana, W. 2001. Himpunan Peraturan Perundang-Undangan Dalam Lingkungan Peradilan Agama. Jakarta: Direktorat Pembinaan Peradilan Agama. 